\title{
Implementation of Cross-Sectoral Collaboration in the Leptospirosis Control in Jeneponto Regency: A Qualitative Approach
}

\author{
Syamsuar Manyullei ${ }^{1}$, Muh. Fajaruddin Natsir ${ }^{2}$, Wirdayanti ${ }^{3}$ \\ ${ }^{1}$ Assitant Professor at the Environmental Health Department,Public Health Faculty, Hasanuddin University, \\ ${ }^{2}$ Instructor at the Environmental Health Department,Public Health Faculty, Hasanuddin University, ${ }^{3}$ Research \\ Scholarat the Environmental Health Department,Public Health Faculty, Hasanuddin University
}

\begin{abstract}
Background: Leptospirosis is an infectious disease caused by leptospira sp. and many are found in populations of people who live in rural areas. Leptospirosis is also a zoonotic disease that can be endemic and has adverse economic, social and psychological impacts. Zoonotic disease is closely related to human health, animals, and also the environment so that in controlling and preventing it is necessary to have the involvement or cooperation of various parties absolutely.
\end{abstract}

Objectives: This study aims to determine cross-sectoral partnership through coordination, communication, and collaboration in the context of controlling leptospirosis in Jeneponto Regency.

Method: This study is a qualitative study with a phenomenological design. The number of informants in this study were 14 people. Determination of informants obtained by purposive sampling by determining the criteria of informants who are willing to be interviewed and play an important role in controlling infectious diseases.

Results: The findings of this study showed that communication and collaboration during the control of infectious diseases such as leptospirosis in Jeneponto Regency had been carried out well through a workshop conducted by the puskesmas by inviting other sectors. However, there are obstacles when coordinating that health workers sometimes forget to coordinate with the sectors involved to secure the community. So that the sector is too late to take action when cases occur in the community.

Conclusion: Implementation of cross-sectoral collaboration in controlling leptospirosis has been carried out with good communication and collaboration.

Suggestions: Health workers need to improve their coordination with all sectors in Jeneponto in order to get better leptospirosis control.

Keywords: Leptospirosis, Control, Cross-Sectoral, Jeneponto Regency.

\section{Introduction}

Leptospirosis is a zoonotic disease that is potentially fatal causing endemic in various regions of tropical climates and causing epidemics after heavy rains and floods. This infection results from direct or indirect exposure to infected animals carrying pathogens in their kidney tubules and releasing pathogenic leptospires through urine. ${ }^{1}$ Leptospirosis is an incidental event because the most common host is mouse. ${ }^{14}$ Although many other animals can be used as hosts reservoir, but Rattus norvegicus is the most common source of human infection infected by leptospira bacteria. ${ }^{1}$

Leptospirosis is also commonly called Weil disease. $^{2}$ This disease is spread through urine or blood of animals infected with leptospira bacteria or attack humans through direct contact with water or soil that 
has been contaminated with urine of animals carrying leptospira bacteria. ${ }^{3}$ Risk factors in transmission of diseases transmitted by mice to humans is a factor in environmental conditions as rat habitat. ${ }^{4}$

The International Report of the Leptospirosis Society (ILS) states that Indonesia as one of the tropical countries with relatively high cases of leptospirosis deaths, ranging from $2.5 \%-16.45 \%$ or $7.1 \%$ on average and including the third highest ranking in the world for mortality. ${ }^{2}$ This can be seen in cases of deaths due to leptospirosis in 2015 - 2018 continues to increase. The highest mortality rate is in 2018 which is 148 deaths. ${ }^{5,6}$

Data on leptospirosis cases in South Sulawesi Province in 2016 - 2018 were not found.6 However, if we look at the risk factors for leptospirosis transmission, namely the high rat population that has the potential to infect humans through leptospira bacteria, an intervention is needed to prevent the emergence of leptospirosis cases in the region. Based on the Minister of Health's Regulation Number 50 Year 2017 concerning Environmental Health Standard Quality Standards and Health Requirements for Vectors and Animal Disease Carriers and Control states that when the number of rats in the environment exceeds the quality standard value, it is necessary to control. The standard quality value for mice is $<1 .^{7}$

South Sulawesi Province has found two mice that were positive for leptospira bacteria from seven rat samples that had been examined. The results were obtained from study on the identification of the presence of leptospira serovar bacteria in rat blood serum at Sultan Hasanuddin International Airport. ${ }^{8}$ Whereas areas in South Sulawesi that are at high risk of being contaminated by leptospira bacteria are caused by environmental aspects. The intended environmental aspects are the use of surface water sources and the physical quality of river water that does not meet health requirements. ${ }^{9}$

Based on information from Buludoang Community Health Center surveillance officers in Tuju Village, Bangkala Barat District, Jeneponto Regency in 2019, stated that from the tens of rats that had been examined, two rats were found positive for leptospira bacteria. One of the causes of the discovery of these bacteria is the condition of environmental sanitation that still does not meet health requirements. This can be seen from the achievement of the percentage of healthy homes in 2016 of only $48.57 \%$, and the percentage is categorized as the lowest percentage. ${ }^{10}$ For this reason, an intervention is needed to overcome this problem in the form of health risk interventions. Health risk based interventions can be carried out through integration and synergy of activities across programs and across sectors. Cross-sectoral or other stakeholder cooperation is useful for overcoming the types of disease problems that involve complex interactions between humans, animals and the environment. ${ }^{11}$ Cross-sectoral cooperation or other stakeholders are recommended to be useful for overcoming the types of disease problems that involve interactions complex between humans, animals and the environment.

Health risk-based interventions can be carried out through integration and synergy between cross-program and cross-sector activities. One health is a concept that involves three main elements, namely humans, animals and the environment. So that in the process of applying this concept, it needs to include multidisciplinary collaborations in science related to health, social, economics, human ecology, animal health and biology and environmental sciences.

The application of the concept of one health really requires a good communication, coordination and collaboration in controlling a disease. The importance of coordinated communication in the dissemination of information is the key to successful implementation of one health. In conveying information including standards and objectives of the policy requires the delivery of accurate information to the implementers and must be consistent from various sources of information. Communication within and between organizations is a complex and complicated process. ${ }^{18}$

Cross-sectoral cooperation in overcoming the problem of leptospirosis is very important to see the case of leptospirosis which is still a problem in Indonesia. That is because environmental sanitation that still does not meet health requirements is one of the risk factors for the presence of mice. The study objective of researchers is to find out how the implementation of cross-sectoral cooperation in the context of controlling leptospirosis in Jeneponto Regency. This study can also be used as a reference for stakeholders to collaborate more in controlling leptospirosis. For this reason, researchers are interested in studying the implementation of crosssectoral cooperation in the context of controlling leptospirosis. The results of the study are expected 
to provide useful information for cooperation in the prevention and control of leptospirosis, especially in Jeneponto Regency

\section{Method}

This study was conducted on January 23 - 31, 2020 at Buludoang Health Center, Tuju Village, West Bangkala District, Jeneponto Regency. This study is a qualitative study with a phenomenological design. The number of informants in this study were 14 people consisting of stakeholders from the health sector and other sectors who played an important role in controlling leptospirosis. Determination of the informants obtained using purposive sampling method, where the informants obtained by determining certain criteria in accordance with the objectives of the study.

Data were collected by extracting data from various techniques and sources to clarify information in the field. This primary data was obtained by observation and in-depth interviews (indepth interview) and Focus Group Discussion (FGD). Data obtained from in-depth interviews and Focus Group Discussions (FGD) were carried out manually in accordance with the instructions for qualitative data processing, as well as in accordance with the objectives of this study. Furthermore, the data were analyzed by the thematic analysis method, and interpreted and presented in narrative form.

\section{Results}

Based on information obtained from the results of in-depth interviews and Focus Group Discussion (FGD) on several informants regarding the implementation of cross-sectoral cooperation that has been carried out in Jeneponto District, it was found that the implementation of cross-sectoral cooperation by looking at coordination, communication, and collaboration in controlling infectious diseases (leptospirosis) is indispensable. Cross-sector implementation is needed when new events occur in the community. Based on study that has been done, the results obtained are that most informants said communication was important in cross-sectoral cooperation. This can be seen from the following indepth interview from non-health sector informants:

"Yes, important. Information is obtained from the bottom up or from the level of puskesmas to district. For example, the case of infectious disease that occurred yesterday we made communication so that cross-sector collaboration was effective like yesterday" $(\mathrm{Mr} 1,49)$
This answer was suupported by the answers of other informants from the following health worker:

"Yes ... very important. Because we cannot work individually. In cross-sectoral cooperation, each has a role and they move to influence society because we cannot do it alone. We work together so that communication is very important to be carried out in order to be successful in controlling disease" (HW1, 35)

Whereas study that has been carried out regarding information feedback submitted by health workers in controlling infectious diseases was obtained that cross-sectoral responds well when cases occur. This is evidenced by the following in-depth interview interview from informants:

"When I got the information that a case like this had happened, we immediately went down to help. For example, yesterday we were directly contacted by health workers to provide security to the public against cases that were happening" $(\mathrm{Mr} 2,44)$

This answer was reinforced by one of the following in-depth interview information from the health officer:

"Yes they immediately respond $j i$ and they immediately go down. We go down the field and they help" (HW3, 27)

Based on study that has been done regarding communication barriers in cross-sectoral collaboration in Jeneponto District, it was found that there were no barriers to each informant interviewed. This is evidenced from the following in-depth interview with the health worker informant:

"There are no obstacles during cross-sector collaboration" (HW5, 34)

"Obstacle is almost said to be non-existent, because my superiors immediately carry out instructions to all relevant sectors for handling. So all communication depends on the highest leadership. The highest leadership determines what to do" (HW4, 51)

This answer was strengthened by the answer of one of the cross-sectoral informants during an indepth interview. The following excerpts are related to communication barriers in cross-sectoral cooperation in Jeneponto Regency:

"there are no obstacles and it has been running from a few years ago" $(\mathrm{Mr} 5,56)$ 
Based on study that has been done related to the importance of cross-sector collaboration it was found that the majority of informants considered collaboration important in cross-sectoral collaboration in Jeneponto Regency. This can be seen from the following Focus Group Discussion (FGD) informants from health workers:

"Yes, important. It was related to cross-sector anyway. That all must come along. For example, from health alone, it can't be. There must be cross-sectoral, such as from the sub-district office, the village head to move the community" (HW5, 34)

This answer was supported by the answers of other health workers at the Focus Group Discussion (FGD) which said that cooperation could facilitate disease control. The following is an excerpt from the health worker informant's answer:

"They all work together in accordance with their respective main tasks. Cross-sectoral collaboration starting from villages, sub-district heads, and districts continues to collaborate so that controlling an illness is easy to do" (HW4, 51)

"We work together to control a disease. Especially cadres must always be diligent in monitoring the conditions that are happening in the community. All are responsible both the village head and the village head towards the community environment"(HW9, 38)

The findings were obtained that there were no obstacles in coordination in cross-sectoral cooperation in Jeneponto Regency. The results are proven from the following excerpts from the answers of the health workers during an in-depth interview:

"There are no obstacles in coordinating across these sectors because our communication has also been smooth so far" (W6, 40)

The informants' answers were strengthened by the answers from other sector's informants during the FGD. The following is an excerpt from the informant's answer:

"No obstacle so far" $(\mathrm{Mr} 1,49)$

But rather than that, for this point one of the informants answered that there were obstacles in crosssectoral coordination in Jeneponto Regency. This is evidenced from the excerpts from the informants' answers during FGD as follow:

"When there was a case yesterday, there was a problem in handling the community because of delays from the village security. We are also overwhelmed by social tasks" $(\mathrm{Mr} 5,56)$

These answers were reinforced by the following misinformation answers during in-depth interviews:

"One obstacle that sometimes occurs is when he (health worker) does not coordinate with us who should contribute to protecting the community. Sometimes if something has happened and I just found out, then I will still be there to help to give direction to the community" $(\mathrm{Mr} 4,37)$

But rather than that, for this point one of the informants provided input during an in-depth interview that could be used as advice in the future, the informant said that

"ifyou want to coordinate the road, one of them is to improve communication between fellow health workers and other sectors involved in control" (HW5, 34)

The findings of study related to the implementation of cross-sector collaboration in Jeneponto can be seen from the quotation of the answer from one of the following health informants during an in-depth interview:

"Maintaining the existing ones and if there is anything that needs to be improved, improve it, because it is very important to do it" (HW4, 51)

The informant's answer was strengthened by the answer of one of the informants during the FGD. The informant said that

"Hopefully in the future every month cross-sector will be implemented. Because this cross-sector is only done every quarter. So hopefully it can be implemented every month" (Mr1, 49)

Then for this point, the informant hopes to always confirm if a case occurs. This can be seen from the excerpts from the cross-sectoral informants' answers during in-depth interviews. The informant said that:

"I hope that in the future if something happens like this, please confirm with us" (Mr4, 37)

\section{Discussion}

Analysis of the data in this study can illustrate the implementation of cross-sectoral cooperation in 
the context of controlling leptospirosis in Jeneponto Regency by observing communication, collaboration, and coordination between health workers and related sectors. Leptospirosis control in Jeneponto Regency does not have a special program in handling the disease, but it is associated with controlling infectious diseases. Leptospirosis control in Jeneponto Regency is only done when the results are found during an outbreak.

The direct effect between communication on the implementation of cross-sector collaboration was proven in the study of Hasibuan et al (2016) when analyzing the implementation of the Dengue Fever Disease Control (P2DBD) program in the Medan region. Even his study concluded that communication directly affected the implementation of the P2DBD program. So in line with that, several things make it clear that communication in cross-sectoral collaboration in Jeneponto Regency is the holding of a workshop every three months conducted by the puskesmas by inviting other sectors. With the frequent implementation of the community service program related to problems that are occurring in the community environment, all program implementers understand the purpose, instructions, and series of activities in controlling leptospirosis.Based on the results of in-depth interviews and FGDs from several informants it was found that collaboration in controlling infectious diseases has been established. This is indicated by the statements of several informants about the importance of cross-sector collaboration. The informant considers that when collaboration does not work well, problems that are happening in the community will be difficult to solve. This is in line with the main principles of collaboration, namely the transparency of the process and the involvement of all stakeholders in making a policy. The aspect of collaboration is dialogue, building commitment, goals, and mutual agreement.

Cross-sector involvement in controlling leptospirosis is one of the ways that must be properly maintained and improved. Sectors involved in controlling leptospirosis are the Ministry of Health who plays a role in interventions related to public health and the Ministry of Agriculture that is needed in efforts to control animals or reservoirs carrying disease. In this case, rats are the main reservoir for leptospirosis transmission. However, in this study the researchers did not include the Agriculture Service as an informant because it did not meet the criteria determined by the researcher, namely the presence in the FGD.

Early diagnosis of leptospirosis is needed to reduce the number of patients dying. Health workers in each region need to have a good ability to recognize the epidemiology of leptospirosis in order to be able to make early detection, management and appropriate prevention method to deal with the incidence of leptospirosis around them. Control of leptospirosis also cannot be completed by the health sector but collaboration and coordination between sectors is needed. ${ }^{19}$

Good coordination must be based on cooperation (between the central government, between the central and regional governments, and between regional governments) and mutual understanding by promoting the spirit of equality. So that in carrying out the tasks to deal with Extraordinary Events (EE) or zoonotic diseases are encouraged to optimize the utilization of resources in their respective institutions and encourage integration. Coordination will run continuously if there is mutual trust between institutions and always maintain the trust that has grown. Trust will grow if the commitment to the agreed duties and responsibilities. With the commitment, consistency, and professional in carrying out the tasks, the integrity of the 'group' coordination will go well. ${ }^{12}$ Based on the results of study conducted at the Buludoang Health Center, Tuju Village, West Bangkala District, Jeneponto Regency, it was found that coordination of health informants and other sectors has been carried out. Cross-sectoral and cross-program coordination such as village heads and community leaders who play an active role in mobilizing the community and its members in controlling leptospirosis. For example, each puskesmas activity must have permission from the regional stakeholders, because the regional stakeholders act as the owner of the area for licensing in every activity that will be carried out by the Puskesmas or the Health Office. The puskesmas cooperates with cadres who function as a channel of information between the puskesmas and the general public. ${ }^{13}$

Based on the results of this study, the informant began to understand the importance of coordination in controlling infectious diseases in the community. Cross sector involvement in controlling leptospirosis is carried out through monitoring by the District Health Office as the highest holder in decision making related to efforts to implement leptospirosis control in the region. In this study, the informant also explained that coordination is indeed needed by humans or organizations to achieve the goals together.

The results of the study explained that in carrying out cross-sectoral collaboration, stakeholders have 
been given their respective responsibilities to carry out their respective tasks and functions. Some informants explained that in coordinating with other sectors in handling a case a whatsapp group was made to facilitate communication so that coordination was carried out well. So that in controlling leptospirosis or other diseases that are endemic in the community environment can be resolved quickly and accurately.

\section{Conclusions}

Based on the results of study that has been carried out on the implementation of cross-sectoral cooperation in the context of controlling leptospirosis in Jeneponto Regency, the researcher draws the conclusion that crosssectoral collaboration that has been carried out so far still needs to be improved. Considering the results of in-depth interviews that have been conducted, the informant said that coordination in cross-sectoral cooperation still needs to be well coordinated with the sectors that should be involved in disease control. However, this information is different from the answers of the informants in the FGD which said that the coordination that had been carried out so far needed to be maintained, bearing in mind that the handling of cases that had occurred in Jeneponto Regency had been well coordinated by the sectors involved in the control. It is suggested for stakeholders to improve coordination by always conducting crosssector workshops every month to evaluate the results of work that has been carried out and the things that need to be improved through coordination.

Ethical Clearance: The study obtained ethics approval from the Health Research Ethics Committee of Public Health Faculty, Hasanuddin University.

Source of Funding: Self-funded.

Conflict of Interest: All authors have no conflict of interest in this study.

\section{References}

1. Adler, B. Leptospira and Leptospirosis', in. Springer, p. 2014.

2. Situmorang, P. R. Gambaran pengetahuan masyarakat tentang leptospirosis di lingkungan II kelurahan pekan labuhan kecamatan medan labuhan, Jurnal Ilmiah Keperawatan IMELDA. 2017: 3(2), pp. 315 - 323.

3. Maiyulis, Syahrizal, M. and Munthe, P. G. Sistem Pakar Mendiagnosa Penyakit Leptospirosis
Menerapkan Metode Rule Base Reasoning, Informasi dan Teknologillmiah (INTI). 2018: 13(1), pp. $34-39$.

4. Ikawati, B., Sulistiyani and Nurjazuli. Analisis Karakteristik Lingkungan Pada Kejadian Leptospirosis di Kabupaten Demak Jawa Tengah Tahun 2009, Media Kesehatan Masyarakat Indonesia. 2009: 8(2), pp. 39-45. doi: 10.14710/ mkmi.9.1.33 - 40.

5. Kementerian Kesehatan Republik Indonesia. Petunjuk Teknik Pengendalian Leptospirosis. DirektoratJendral Pengendalian Penyakit dan Penyehatan Lingkungan Kementrian Kesehatan Republik Indonesia. Jakarta. 2017.

6. Kementerian Kesehatan Republik Indonesia. Profil Kesehatan Indonesia 2017. Direktorat Jendral Pengendalian Penyakit dan Penyehatan Lingkungan Kementrian Kesehatan Republik Indonesia. Jakarta. 2018.

7. Kemenkes, RI. Peraturan Menteri Kesehatan Republik Indonesia Nomor 50 Tahun 2017 Tentang Standar Baku Mutu Kesehatan Lingkungan dan Persyaratan Kesehatan UntukVektor dan BinatangPembawaPenyakit Serta Pengendaliannya, Menteri Kesehatan Republik Indonesia Peraturan Menteri Kesehatan Republik Indonesia. 2017.

8. Andis, A.M. Identifikasi Keberadaan Serovar Bakteri Leptospira pada Serum Darah Tikus di Bandar Udara Internasional Sultan Hasanuddin Menggunakan Metode Microscopic Aglutination Test (MAT). Skripsi. Departemen Kesehatan Lingkungan Fakultas Kesehatan Masyarakat Universitas Hasanuddin. 2018.

9. Syamsuar. et al. Environmental Health Risk Assessment in Flood Prone Area; Case Study in Wajo District, International Journal of Science and Healthcare Research. 2018: 3(4),pp. 9 - 16.

10. Depkes. Profil Kesehatan Provinsi Sulawesi Selatan Tahun 2016. Makassar. 2017.

11. Cleaveland, S. et al. One Health contributions towards more effective and equitable approaches to health in low- and middle-income countries, Jurnal The Royal Society. 2017: 372(1), pp. 1 - 11.

12. Kementerian Koordinator Bidang Pembangunan Manusia dan Kebudayaan. Pedoman Koordinasi Lintas Sektor (Menghadapi Kejadian Luar Biasa (KLB)/Wabah Zoonosis dan Penyakit Infeksi Emerging (PIE). Jakarta. 2018. 
13. Wati, M. S., Mateus, S. A., \& Lintang, D. S. Jenis Upaya, Sarana Prasarana, dan Keterlibatan Instansidalam Pengendalian Faktor Risiko Leptospirosis di Kota Semarang, Jurnal Kesehatan Masyarakat (e-Journal). 2017: 5(2), 2356 - 3346.

14. Pasaribu, A. O., Mesran and Hasan, Y. Sistem Pakar MendiagnosaPenyakit Kaki Gajah Menggunakan Metode Certainty Factor, Jurasik (Jurnal Riset Sistem Informasi dan Teknik Informatika). 2018: 17(4), pp. 375 - 381.

15. Cleaveland, S. et al. One Health contributions towards more effective and equitable approaches to health in low- and middle-income countries, Jurnal The Royal Society. 2017: 372(1), pp. 1 -

16. Direktur Jenderal Pengendalian Penyakit dan Penyehatan Lingkungan. 2015. Rencana Aksi Program Pengendalian Penyakit dan Penyehatan Lingkungan Tahun 2015 - 2019.
17. Agungpriyono, S., Purnawarman, T. and Suprayogi, A. Pengembangan Kompetensi Utama One Health (One Health Core Competency, OHCC) Dalam Kurikulum Pendidikan Kedokteran Hewan, Jurnal Palembang, 2014: 1(1), pp. 169 - 171.

18. Munggaran, G.A., Gambaran Implementasi Kebijakan Pengendalian Demam Berdarah Dengue (DBD) Melalui Program Gerakan 1 Rumah 1 Jumantik di Puskesmas Kelurahan Benda Baru Kota Tangerang Selatan Tahun 2017. Skripsi. Universitas Islam Negeri Syarif Hidayatullah Jakarta. 2018.

19. Pujiyanti, A. dkk., 2019. Pengetahuan Petugas Kesehatan dan Lintas Sektor Tentang Leptospirosis di Kabupaten Pati, Vektora, 11(1), pp. 39 - 46. 